\title{
Impact of Mass Media on Agriculture Practices in District Lucknow (U.P), India
}

\author{
Vishakha Yadav ${ }^{1}$, S. R. Yadav ${ }^{1}$, Abhishek Mishra ${ }^{1}$ and Pratima Sachan ${ }^{2}$ \\ ${ }^{1}$ Department of Agricultural Extension, CSAUA\&T, Kanpur-208002 (U.P.) India \\ ${ }^{2}$ Department of Home Science Extension, CSAUA\&T, Kanpur-208002 (U.P.), India \\ *Corresponding author
}

\section{A B S T R A C T}

Keywords

Mass media, Agriculture, farmers, Socioeconomic

\section{Article Info}

Accepted:

12 March 2020

Available Online:

10 April 2020
The study entitled "Impact of mass media on agriculture practices in district Lucknow (U.P.)" was undertaken with a view to analyze the socio-economic background of the farmers followed by impact of mass media on adoption of agriculture practices, adoption of agricultural practices, and constraints faced by respondents and then the suggestions; study revealed that majority ( 58.75 per cent) of the respondents were old age group with middle school level of education ( 42.50 per cent) having small land holdings ( 51.25 per cent) out of which majority of farmers were having medium (42.50 per cent) annual income. Among formal inter-personal sources village agricultural workers were the main and most credible sources of information. Among mass media and print media radio, television, newspaper and magazines were the main and most credible source of information. From the study it was revealed that socio-economic characteristics had positive and significant relationship factors influencing availability of the farm produce. Percentages and frequency were showing the impact of mass media under use and no use of mass media on agriculture practices such as land preparation, seed and sowing, fertilizer management, irrigation management, harvesting etc. There were significant adoption and improvement seen in the study.

\section{Introduction}

Agriculture is the soul economy in countries like India, and mass media is an important component of strategy recognized in the revitalization of agriculture extension system. For over a half of century social scientist have explored the impact of mass media on agriculture and focused to think about it as previously mass media and communication was not seen as the major priority between national as well as international level in agricultural development and was undervalued. The print media got the $3^{\text {rd }}$ position after fellow farmers and television.

The most used form of print media for agricultural information was pamphlets followed by posters, newspaper, book/booklets, magazines and journals. In view of increases in literacy level to $52.11 \%$ during 1991, print media has acquired a 
greater role in dissemination of information on improved agriculture practices to the farming community and also to inform the public in general. Increasing rate of literacy in India offering new promises and prospects for utilizing print medium as a means of mass communication. In the view of increase in literacy level to $52.11 \%$ during 1991, print media has acquired a greater role in dissemination of information on improved agricultural practices to the farming community. Farmers are now becoming very much efficient and taking latest update and knowledge related to agricultural activities immediately after the introduction of new technology, tools and varieties.

By considering all these facts that how farming of these days should be treated and depend upon mass media. It is important factor to enter in process of adoption of improved farm practices that starts from awareness means giving knowledge from different source of information about agriculture, horticulture and animal husbandry practices. Hence this study has been framed by research entitled Impact of Mass Media on Agriculture development in Chinhat block, district Lucknow (U.P.).

\section{Materials and Methods}

This part deals with the methods and procedures followed in studying the objective of present study. Firstly location of the study taken under which selection of district was done purposively while the selection of block, village and respondents were done on random basis. Hence, no. of blocks, no. of villages and no. of respondents 80 were selected for the study. After that dependent variable which was knowledge level of farmer when not use and use of mass media and then independent variable including age, education, caste, land holding etc. by the method of direct questioning was done. Wheat crop was taken as a reference for knowledge of farmers for use and not use of mass media and through knowledge index scoring was done.

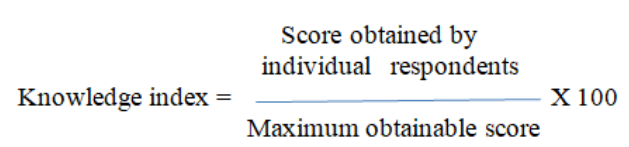

The practices taken under wheat crop cultivation to compare knowledge of farmers when not use of mass media and use of mass media are:- Land preparation, seed and sowing, fertilizer management, plant protection measures, irrigation management, harvesting and threshing and marketing and produce.

Technique for data collection structured interview schedule was used. Distribution of the score done $4,3,2,1 \& 0$ for daily, weekly, rarely and never use. The information arranged in the tabular form and simple random technique was used for the collection of data. All the information were directly taken by the respondents by direct questioning and then according to the scores obtain graphs and tables were prepared.

\section{Results and Discussion}

The profile of farmers involved in farming was maximum from the age above 55 which were around (58.75\%) then mostly respondents were educated up to middle school only $(42.50 \%)$. According to land holding maximum farmers belongs in the category of small (1-2 ha) and holding $(51.25 \%)$. Mostly farmers were depending upon farming only.

The study of when use of mass media and not use of mass media under wheat cultivation practices included- land preparation, seed and sowing, fertilizer management, plant protection measures, irrigation management and harvesting (Fig. 1 and 2). 
Table.1 Distribution of respondents according to their age

\begin{tabular}{|c|c|c|c|}
\hline S.No. & $\begin{array}{c}\text { Age } \\
\text { category(years) }\end{array}$ & $\begin{array}{c}\text { No. of } \\
\text { Respondent }\end{array}$ & Percentage \\
\hline 1. & Young ( 15- 35) & 12 & 58.75 \\
\hline 2. & Middle (35 to 55) & 21 & 26.25 \\
\hline 3. & Old (above 55) & 47 & 15.00 \\
\hline & Total & $\mathbf{8 0}$ & $\mathbf{1 0 0 . 0 0}$ \\
\hline
\end{tabular}

The overall mean distribution of the respondents presented in above table concludes that maximum number of respondents (58.75) per cent were of old age group followed by middle age group with (26.25) percent and young age group (15.00) percent.

Table.2 Distribution of respondents according to their education

\begin{tabular}{|l|l|l|l|}
\hline S.No. & Literacy & \multicolumn{2}{|l|}{ Respondents } \\
\cline { 3 - 4 } & & Number & percentage \\
\hline 1. & Illiterate & 5 & 06.25 \\
\hline $\mathbf{2 .}$ & Primary & 10 & 12.50 \\
\hline $\mathbf{3 .}$ & Middle & 34 & 42.50 \\
\hline $\mathbf{4 .}$ & High school & 15 & 18.75 \\
\hline $\mathbf{5 .}$ & Intermediate & 11 & 13.75 \\
\hline $\mathbf{6 .}$ & Graduation & 05 & 06.25 \\
\hline & Total & $\mathbf{8 0}$ & $\mathbf{1 0 0}$ \\
\hline
\end{tabular}

It is clear from the above table that only 06.25 percent of respondents are illiterate. There were about 12.50 percent graduates and 42.50 percent have gone to primary and adopted agriculture as a profession. The highest number of respondents were in the category who have went to middle school 18.75 percent followed by high school 13.75 percent, about 06.25 percent respondents standard up to intermediate, over all the education level of respondents was good

Table.3 Distribution of respondents according to land holding

\begin{tabular}{|c|c|c|c|}
\hline S.No. & Land holding & No. of respondent & Percentage \\
\hline 1. & Marginal (up to 1 ha) & 25 & 31.25 \\
\hline 2. & Small (1-2 ha) & 41 & 51.25 \\
\hline 3. & Large (2 ha and above) & 14 & 17.50 \\
\hline & Total & $\mathbf{8 0}$ & $\mathbf{1 0 0 . 0 0}$ \\
\hline
\end{tabular}

The above table indicates that the majority of respondents 31.25 percent had small land holding, 51.25 percent had marginal land holding. The large farmers among the respondents were only 17.50 percent. Hence, it may be concluded that the holding of the farmers on an average under study were dominantly medium size. And they were more responding towards adoption of new techniques with the help of mass media. 
Table.4 Distribution of farmers on the basis of knowledge regarding land preparation practices in wheat crop

\begin{tabular}{|c|c|c|c|c|c|}
\hline S.No. & Category & \multicolumn{2}{|c|}{$\begin{array}{c}\text { Not use of mass } \\
\text { Media }\end{array}$} & \multicolumn{2}{c|}{ Use of mass media } \\
\cline { 3 - 6 } & & Frequency & Percentage & Frequency & Percentage \\
\hline 1. & Low & 28 & 35.00 & 30 & 25.00 \\
\hline 2. & Medium & 23 & 28.75 & 27 & 33.75 \\
\hline 3. & High & 29 & 36.25 & 33 & 41.25 \\
\hline & Total & $\mathbf{8 0}$ & $\mathbf{1 0 0}$ & $\mathbf{8 0}$ & $\mathbf{1 0 0}$ \\
\hline
\end{tabular}

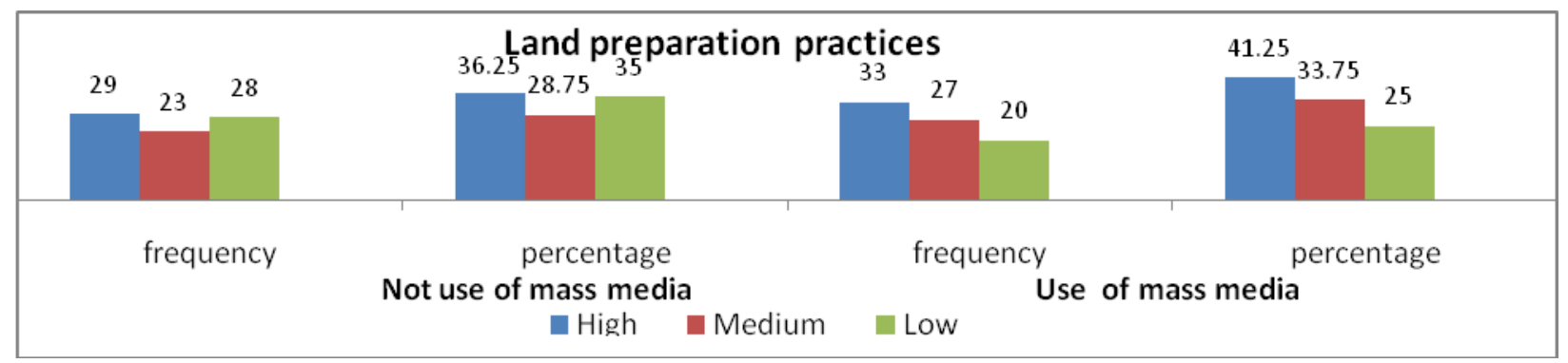

Fig.1

Above table concludes when not use of mass media of wheat crop practices, maximum farmers were having 35.00 per cent of low knowledge about land preparation practices, followed by high level of 36.25 per cent and medium level of knowledge 28.75 per cent respectively. But when mass media is use regarding land preparation in crop, majority of the farmers 41.25 per cent were having high level of knowledge, followed by medium level 33.75 per cent and low level of 25.00 per cent.

Table.5 Distribution of the farmers on the basis of knowledge regarding the fertilizer management practices in wheat

\begin{tabular}{|c|c|c|c|c|c|}
\hline \multirow{2}{*}{ S.No. } & Category & \multicolumn{2}{|c|}{$\begin{array}{c}\text { Not use of mass } \\
\text { Media }\end{array}$} & \multicolumn{2}{c|}{ Use of mass media } \\
\cline { 3 - 6 } & & Frequency & Percentage & Frequency & Percentage \\
\hline 1. & Low & 22 & 22.50 & 13 & 16.25 \\
\hline 2. & Medium & 40 & 50.00 & 45 & 56.25 \\
\hline 3. & High & 18 & 27.50 & 22 & 27.50 \\
\hline & Total & $\mathbf{8 0}$ & $\mathbf{1 0 0}$ & $\mathbf{8 0}$ & $\mathbf{1 0 0}$ \\
\hline
\end{tabular}

The above given table concludes that when no use of mass media a large number of farmers (50.00 per cent) were having medium level of knowledge of fertilizer management in wheat crop, followed by the farmers (27.50 per cent) were having low level of knowledge and then high knowledge (22.50 per cent). But when mass media is used by the farmers, we found that majority of the farmers were having medium level of knowledge (56.25 per cent) followed by high level of knowledge (27.50 per cent) respectively while (16.25 per cent) farmers were having low level of knowledge. 
Table.6 Distribution of the farmers on the basis of knowledge regarding plant protection measures in wheat crop under use and not use of mass media

\begin{tabular}{|c|c|c|c|c|c|}
\hline S.No. & Category & \multicolumn{2}{|c|}{$\begin{array}{c}\text { Not use of mass } \\
\text { Media }\end{array}$} & \multicolumn{2}{c|}{$\begin{array}{c}\text { Use of mass } \\
\text { Media }\end{array}$} \\
\cline { 3 - 6 } & & Frequency & percentage & Frequency & percentage \\
\hline 1. & Low & 42 & 52.50 & 30 & 37.50 \\
\hline 2. & Medium & 10 & 12.50 & 18 & 22.50 \\
\hline 3. & High & 28 & 35.00 & 32 & 40.00 \\
\hline & Total & $\mathbf{8 0}$ & $\mathbf{1 0 0}$ & $\mathbf{8 0}$ & $\mathbf{1 0 0}$ \\
\hline
\end{tabular}

The above table indicate that before the information about plant protection measures majority of the farmers ( 52.50 per cent) were having low level of knowledge about plant protection measures, followed by farmers (35.00 per cent) having high level of knowledge and medium level of knowledge (12.50 per cent). While those who used mass media for integrated wheat crop package practices, maximum farmers about(40.00 per cent) were coming under the category of high level of knowledge, followed by the farmers having low level of knowledge (37.50 per cent) and medium level of knowledge with (22.50 per cent). It shows that mass media is having good impact among the farmers under study.

Table.7 Distribution of the farmers on the basis of knowledge related to harvesting and marketing of wheat crop under no use of mass media and use of mass media

\begin{tabular}{|c|c|c|c|c|c|}
\hline S.No. & Category & \multicolumn{2}{|c|}{ Not use of mass Media } & \multicolumn{2}{|c|}{ Use of mass media } \\
\cline { 3 - 6 } & & Frequency & Percentage & Frequency & Percentage \\
\hline 1. & Low & 42 & 52.50 & 17 & 21.25 \\
\hline $\mathbf{2 .}$ & Medium & 24 & 30.00 & 30 & 37.50 \\
\hline 3. & High & 14 & 17.50 & 33 & 41.25 \\
\hline & Total & $\mathbf{8 0}$ & $\mathbf{1 0 0}$ & $\mathbf{8 0}$ & $\mathbf{1 0 0}$ \\
\hline
\end{tabular}

Harvesting and marketing

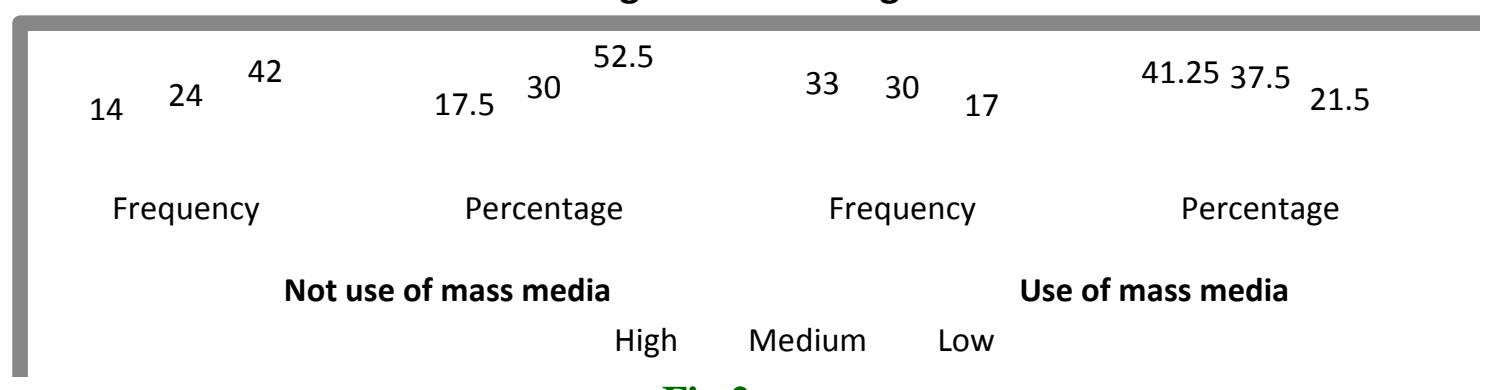

Fig. 2

Above table reflects that before application of mass media a large number of farmers $(52.50$ per cent) were having low level of knowledge about harvesting and marketing wheat crop, followed by the farmers ( 30.00 per cent) were having medium level of knowledge and high level of knowledge (17.50 per cent) respectively. 
But after use of mass media we found that maximum no. of farmers (41.25 per cent) were having high level of knowledge. While (37.50 per cent) farmers were having medium level of knowledge and (21.25 per cent) farmers were found with low level of knowledge.

Table.8 Prioritization of different cultivation practice by the farmers during use of mass media

\begin{tabular}{|c|c|c|c|c|c|}
\hline \multirow{2}{*}{ S.No. } & Particulars & \multicolumn{4}{|c|}{ Prioritization of farmers } \\
\cline { 3 - 6 } & & High & Medium & Low & Total \\
\hline 1. & Land preparation & 25 & 39 & 16 & $\mathbf{8 0}$ \\
\hline 2. & Seed and sowing & 52 & 19 & 09 & $\mathbf{8 0}$ \\
\hline 3. & Fertilizer management & 41 & 28 & 11 & $\mathbf{8 0}$ \\
\hline 4. & Irrigation management & 36 & 24 & 20 & $\mathbf{8 0}$ \\
\hline $\mathbf{5 .}$ & Plant protection measures & 40 & 25 & 15 & $\mathbf{8 0}$ \\
\hline 6. & Harvesting and threshing & 29 & 32 & 19 & $\mathbf{8 0}$ \\
\hline 7. & Marketing of produce & 46 & 21 & 13 & $\mathbf{8 0}$ \\
\hline
\end{tabular}

After getting a range of information on integrated wheat crop practices, small farmers prioritized plant protection, seed information and market price as the most important. Farmer close to $65 \%$ ranked seed information as the highest priority while over $57.5 \%$ given market prices as the most important category (Table 8).

Maximum no. of respondents was old age $(58.75 \%)$, literacy percentage of respondents observed $(93.75 \%)$ and maximum no. of respondents were having small land holding $(51.25 \%)$. In case of annual income maximum respondents was having medium annual income (42.50 percent). Farming alone was the main occupation of the maximum number of respondents (56.25 percent).

When mass media was not in use the cultivation practices for the crop production, it was analyzed that maximum farmers were having low level of knowledge regarding land preparation i.e. $36.25 \%$, for seed and sowing $40 \%$, for fertilizer management medium level i.e. $50.00 \%$, for plant protection, harvesting and marketing low level i.e., $52.50 \%$ etc. While after use of mass media there is increased in knowledge level of farmers from low to high i.e., $40.25 \%, 42.50 \%, 41.25 \%$ respectively. Even priorities were seen in marketing of produce and fertilizer management.

\section{References}

Adeniji, O.B and Ega, L.A. (2006). “Assessed the impact of mass-media extension activities on awareness", Journal of Agriculture, Forestry and social sciences, (4): 89-88.

Anita and Singh, Y.P. (1995). Agents of developments; a profile Indian Journal of extn. Edu. .131 (1\&4): 25-29.

Bhagyalaxmi, K. Gopala Krishna Rao, V. and sudarshanreddy, M. (2003). Profile of the rural women micro entrepreneurs. Journal of Research Acharya N.G. Ranga agriculture university, Hyderabad 51 (4): 51-54

Mooventhan, P. and Philip, H. (2012). Connectivity of the internet to different kind national research centre on Meat, (ICAR), Hyderabad, Indian research journal of Extension Education, 12(2): 43-47. 
Singh M.P. and Yadav, A. (2007) Among the different media, method demonstration cum skill teaching project directorate for Cropping System Research, Modipuram, Meerut-250 110 U.P. 7(1): 191-193.
World Bank (2002). Information and Communication Technologies in Agriculture. Rural Development Department, Draft. Unpublished August, 2003.

\section{How to cite this article:}

Vishakha Yadav, S. R. Yadav, Abhishek Mishra and Pratima Sachan. 2020. Impact of Mass Media on Agriculture Practices in District Lucknow (U.P), India. Int.J.Curr.Microbiol.App.Sci. 9(04): 1313-1319. doi: https://doi.org/10.20546/ijcmas.2020.904.155 